\title{
What Can Urban Gardening Really Do About Gentrification? A Case-Study of Three San Francisco Community Gardens
}

\section{Guillaume Marche}

\section{(2) OpenEdition Journals}

Electronic version

URL: https://journals.openedition.org/ejas/11316

DOI: $10.4000 /$ ejas. 11316

ISSN: 1991-9336

Publisher

European Association for American Studies

\section{Electronic reference}

Guillaume Marche, "What Can Urban Gardening Really Do About Gentrification? A Case-Study of Three San Francisco Community Gardens", European journal of American studies [Online], 10-3 | 2015

document 1.7, Online since 31 December 2015, connection on 08 July 2021. URL: http:// journals.openedition.org/ejas/11316 ; DOI: https://doi.org/10.4000/ejas.11316

This text was automatically generated on 8 July 2021 .

Creative Commons License 


\title{
What Can Urban Gardening Really Do About Gentrification? A Case- Study of Three San Francisco Community Gardens
}

\author{
Guillaume Marche
}

\section{Introduction: Of Gardens and Gentrification}

Among other characteristics, San Francisco is known for its relatively small acreage of 46.9 square miles and its high population density of 17,620 people per square mile, making it the second-most densely populated major city in the United States after New York City. Due to its attractiveness, the City by the Bay's population is steadily increasing, which leads to a housing shortage, and the value of real-estate in San Francisco has skyrocketed since the early 1990s, especially since the late 1990s' "dotcom" bubble, and it is currently being pushed by the new "tech" bubble. This has resulted in a steady process of gentrification over the past twenty years, which has intensified in the recent past, with new, sometimes unexpected neighborhoods being affected: while gentrification in areas like the Mission has been going on for twenty years at an increasing pace, it is moving further and further south, spilling over into adjacent neighborhoods such as Bernal Heights and Potrero Hill. Gentrification has more recently overflown into historically working-class, ethnic- and racial-minority, or generally disreputable neighborhoods like Bayview, the Western Addition, South of Market and the Tenderloin, some of which are regarded nowadays as a new frontier of middle- to upper-middle-class, mainly white, residential expansion. 
Gentrification is one particularly critical aspect of the territorial conflicts that are habitual in San Francisco, given the city's contested transformations ever since its initial period of post-war growth in the 1960s. ${ }^{1}$ And the disputed uses and appearance of public spaces is among the guises this contestation assumes. From a Lefebvrian perspective, indeed, the right to the city is not only a question of access to urban resources, but also a matter of being able to shape and transform them. Thus, beautification assumes political significance since it may, on the one hand, enhance the attractiveness of otherwise disreputable neighborhoods: murals or urban greening initiatives-such as community gardens and urban farms-are interventions in public spaces that improve the quality of residents' lives. Yet, on the other hand, they may express a claim for legitimate use of urban space and for an equitable living environment, so that it is unclear whether they heighten the gentrifying transformation of such neighborhoods, or whether they may support inhabitants' resistance to being pushed out.

In fact, most scholarship on urban greening focuses on areas such as New York City, where land is scarce, real estate values are high, and more or less informal garden projects have been viewed as forms of resistance to urban development and capitalist urban growth. ${ }^{2}$ This is mainly true of studies of historical contexts where local governments have viewed urban greening as a form of insubordination to be suppressed, while more recently, since the early 2000s, even the municipality of New York has sought to coopt urban greening into its own smart growth agenda. Scholarship-as well as the media-has also paid attention to recent urban gardening and farming initiatives in the context of the Great Recession, typically in New Orleans after Hurricane Katrina and in Detroit and other cities deeply affected by the foreclosures and evictions resulting from the subprime crisis. ${ }^{3}$ In such environments, local residents' (literally) grassroots initiatives are a concerted form of resistance, both to food deprivation, in a way that harks back to the Great Depression, and, more generally, to the loss of civil and economic empowerment.

But San Francisco represents a different environment where land is scarce, real estate values are getting higher, and city government authorities do support urban growth projects-in Mission Bay or the Waterfront front for example. Yet, more or less informal garden projects are also actively encouraged by city government authorities. If San Francisco is to ride the urban growth wave and reap benefits in terms of tax revenue, it would seem to make more neoliberal business sense to favor intensive urban development. But the fact is that, along with murals and other forms of beautification, urban greening initiatives in general fit in with the alternative urban model that San Francisco represents and which makes it so attractive to what Richard Florida has named the "creative class." ${ }^{4}$ The municipal government's support for such forms of bottom-up urban improvement is thus consistent with its desire to maintain high real estate prices in 
order to accommodate, and even support, the city's attractiveness for high-income tier residents and thus salvage its revenue basis and its status as a world-class metropolis. Yet, San Francisco is a reputed haven of municipal liberalism, with social services and a century-old ethos of social inclusion and egalitarianism that has very few equivalents-especially on that scale-in the United States. ${ }^{5}$ Thus, the City of San Francisco is faced with an internal conflict since it has a rather ambivalent attitude when it comes to balancing poor people's socioeconomic rights with the tax revenue generated by urban development and the resulting influx of households in the upper income bracket.

In this context, an important question when it comes to garden projects is whether they may be a way for communities besieged with ever-expanding, apparently unstoppable gentrification to resist it and make a territorial claim on their neighborhoods, or if it may actually be detrimental and counterproductive insofar as greening contributes to turning otherwise fairly unpalatable neighborhoods into attractive areas for $21^{\text {st }-c e n t u r y ~ m i d d l e-~ t o ~ u p p e r ~ m i d d l e-c l a s s ~ u r b a n ~ " p i o n e e r s . " ~ O r ~ m a y ~}$ garden projects actually result from gentrifiers' desire to "improve" their neighborhood and thus succeed in enhancing that very attractiveness? Or do these questions make sense at all? Do urban greening initiatives have any impact whatsoever, or are the macroeconomic mainsprings of San Francisco's changing demographics simply out of proportions with whatever control ordinary folks can possibly exert over their situations? Thus the issue here is not so much how city denizens interact-i.e. conflict or cooperate-with municipal government institutions, as how residents interact with each other in seeking to grapple with broad economic and social processes that largely escape their control.

6 This study is based on fieldwork conducted in San Francisco in 2012 and 2013 and examines three very distinct community gardens, which will henceforth be referred to as "organized garden projects"-after Mary Beth Pudup-in order not to take their community-building dimension for granted, since this is one of the issues these examples raise. ${ }^{6}$ The first of these organized garden projects is located in a section of the only remaining predominantly African American neighborhood in San Francisco, which is currently undergoing rather fast gentrification, partly due to its location on a hillside offering outstanding views of the San Francisco Bay. The latter two garden projects studied here are located on either side of the same hill in the southeastern part of the city: while the north side of the hill has been gentrified since the 1990s, the south side has long been home to a historical public housing project largely inhabited by African Americans. As of the time of fieldwork, this housing project dating back to the 1940s was in the process of being redeveloped, that is to say torn down and built up again into a mixed-income neighborhood. I begin by presenting and contrasting the first two cases, because they are opposites in many ways-the most evident of which being the 
divergence between an area that is yet in the process of gentrification and a neighborhood that has already been gentrified. I subsequently analyze the third case and compare it with the former two, because it stands as a counterexample since it was not initiated from below, by the residents, but from above, by the agency in charge of the neighborhood's renovation. Yet, it proves to be more than a mere "control" case, since it evinces dynamics that the previous binary does not suffice to explain.

\section{Organized Garden Projects as a Form of Resistance}

7 The first example studied here is almost a textbook variety of an organized garden project initiated in a lower-income neighborhood by two local residents, an older African American couple, who gained the interest and support of their neighbors and triggered a collective, community-based initiative to plant on "little plots of dirt" on median strips, on unused street sides, on sloping narrow triangular plots near intersections. ${ }^{7}$ The project was started in 2001, it has grown to have a budget of $\$ 168,000$ in public grants, one full-time paid staff member and operates 4 different gardens within a range of a few blocks. In this sense, it is not a purely informal, guerrilla-style urban-greening initiative: it has rules and organization. ${ }^{8}$

8 In particular, one of its rules is that before anyone can start a garden or make significant changes to an existing one, they have to seek agreement from the collective-which means it is not so spontaneous, but this springs from a commitment to building community by getting decisions to be made in a communal way. This is a way to ensure that the residents always have a say in deciding what the spaces near which they live are going to look like, which is particularly poignant in a context where the neighborhood is undergoing major change that is not of the residents' choosing. What makes it all the more important is that the City is facilitating the remodeling of such neighborhoods in transition through a "smart growth" agenda of walkable, green neighborhoods and sustainable urbanism, an agenda that authors like Noah Quastel and Melisa Checker, among others, have shown is characteristic of "environmental gentrification."

In so doing, the residents manifest that they have come to terms with the fact that their neighborhood is going to be remodeled and changed, but they want to have some say in how this is to be done. ${ }^{10}$ They come across as an embattled community whose members have reinforced their community ties in the past ten years in order to improve their quality of life. Tellingly, the evil they were fighting at first was crime and insecurity on the block, which they addressed by fostering solidarity among neighbors, talking to each other, looking after each other. In this sense, they should not be characterized as a besieged community that is resistant to any sort of change. In fact, scholarship suggests that smart growth does not have to result in 
enhanced gentrification and de facto racial segregation. ${ }^{11}$ But this lowincome, predominantly African American community is now faced with gentrification-a giant that it cannot possibly defeat but which it can at least attempt to domesticate.

Faced with the threat of the disappearance of the neighborhood's identity and history, they want to preserve it not just through artifacts, but also through practices. In addition to greening, the organized garden project, for example, sponsors the creation of murals that celebrate the community's heritage, as in the mural dedicated to the project's founders. These green and beautified spaces are not just ends in themselves, but they are meant to facilitate collective practices, such as meeting at the mural, sitting on a bench and discussing future planting ideas. In fact, the organization counts addressing gentrification as one of its missions and accomplishments. ${ }^{12}$ The participants do not delude themselves that their small-scale efforts may guarantee David's triumph over Goliath, but they offer a response that reflects both a fairly sensible appreciation of the uneven balance of powers and a determination not to give in to the adverse circumstances. In other words, they do not seek to fight face-on, but they do so in an oblique, indirect way, and thus generate empowerment.

\section{Beautification as a Vehicle of Gentrification}

11 The second case for this study is situated on the already gentrified northern side of a hill, a residential neighborhood that is fairly remote from the center of San Francisco but offers a pleasant environment with fairly low density, a good choice of local stores, cafés and restaurants, and extremely picturesque views of both the San Francisco Bay and the city. The garden project was started in 2008 on the initiative of a single person whose apartment overlooked a vacant plot of land on a freeway off-ramp across the street and who just wanted to make it look less ugly by greening it. The resulting garden thus sprang from a purely individualistic desire to improve the appearance of a familiar urban environment. It was only subsequently that the community side of things kicked off. Once neighbors noticed the initiative, they made encouraging comments and supported the initiator when she decided that the garden was growing too big to keep under the radar. If she had had a choice, she would have much rather kept it not just informal, but also as private as possible, considering that the land is public property. Interestingly, the initiator draws a very sharp contrast between her initial move and what the garden has grown to become, namely a gathering place, a connection among neighborhood residents. ${ }^{13}$

In2 a sense, there is a strong similarity between the two organized garden projects in that both foster a bond among participating neighborhood residents; in both cases the stakes are to claim ownership of one's environment by placing an imprint on its physiognomy. But there are two fundamental, corollary differences 
between the two projects. First, the former project's organization follows a bottom-up, collective decision-making process, whereas the structure of the latter, as per the garden project initiator's own admission, is essentially that two people make decisions and everyone else is invited to volunteer. This, she considers, makes for more efficiency and less waste of time in lengthy discussion. With her practical turn of mind and her great sense of individual initiative, she is keen to ward off anything that stands in the way of the goals she has set for herself. Second, one is a case of residents whose neighborhood is being gentrified and who seek to leave a physical imprint on their environment so as to symbolically preserve their legacy, whereas the other consists in residents with socioeconomic privilege claiming ownership of the turf they seek to improve through a beautification initiative. ${ }^{14}$ For example, although she is a tenant-in an area that still has a stable percentage of tenant-occupied housing units verging on two thirds, i.e. comparable to San Francisco as a whole-the initiator is a professional in the creative sector with a cosmopolitan background. She is rather representative of the neighborhood's gentrification, as measured by-compared to the rest of city-a roughly twice higher, faster growing median household income, percentage of residents with a Master's degree or more, and percentage of households with an annual income of more than $\$ 150,000 .{ }^{15}$

Consistently, the latter organized garden project has appealed to a 70-strong team of neighborhood residents who volunteer one Saturday morning a month to improve the neighborhood's aesthetic standards by creating a pleasant, relaxing environment. Both the initiator's discourse and the organization's website do mention the goal of educating visitors and volunteers about botany, but the pictures on the garden's website emphasize an image of natural beauty and harmony, and the founder's language enhances "an escape from the city" over education. ${ }^{16}$ By contrast, if websites are a good indicator of what organizations purport to do, the former organized garden project's website shows inhabited and embodied gardens-places where practices represent and signify the ethnic, racial, and generational diversity in the make-up of the community. ${ }^{17}$ Generational transmission is especially important in this case where preserving the memory of a waning African American, working-class heritage has become part and parcel of the project.

The take on gentrification at the already gentrified neighborhood's organized garden project is quite different. For example, one of the projects for developing the initiative is to address the dire state of disrepair of a particular block down the street from the garden-a no-through-way block which, in the words of the garden's initiator, "is disgusting: there's lots of graffiti, and dumping, and homeless encampments." ${ }^{18}$ As a neighborhood community association, the organization has submitted a plan to clean up the block by building a retaining wall and leveling out the ground in the dip where homeless people usually sleep because they can hide, and then planting trees to 
separate the street from the unused plot of land below, adding a sidewalk and greening it. The organized garden project's website shows awareness of how the real estate market will respond to such an improvement: "Current homeowners can also expect their property values to rise as a result of this work: we encourage you to join in with this project!" 19 In the words of the garden's initiator, "joining in" means that she and the single other main project leader "basically call the shots and reach out to professionals [living in the neighborhood] as needed." ${ }^{20}$ The class-inflected nature of the project and its gentrifying intent are rather blatant. That situates this project on a different plane than the usual type of environmental gentrification where, in the words of Noah Quastel, "gentrifiers face systematic moral predicaments as the roles they perform in competitive housing markets undermine their values." ${ }^{21}$ Not much of a moral predicament is to be noticed here.

15 As a provisional conclusion, if we wonder whether organized garden projects may help communities besieged with gentrification to resist it, or if they contribute to turning unattractive neighborhoods into destinations of choice for gentrifiers, the answer should be both. That is to say, an organized garden project can imply one or the other, or it can imply both as the people in charge of the first one studied here are well aware. This is also what Nathan McClintock has shown in his work on urban agriculture's inherent contradictions between its radical/ reformist potential and its neoliberal potential.22 But if we instead wonder what it is about a garden that determines whether it leans toward the empowerment of a neighborhood's current residents, or toward their displacement, the answer would seem to be-following the insight of Efrat Eizenberg ${ }^{23}$-that it depends on whether the garden is individualistic in essence or communitarian. But I would argue, further, that it is also a matter of how horizontal and grassroots the decisionmaking process is-as at the first garden project studied here, where consensus-based decision-making is the rule-or vertical, top-down -as in the second case here, where one or two people "call the shots." A third example will help further explore this issue.

\section{Top-down Greening Initiative and Bottom-up Community-building?}

16 The third organized garden project studied here is located on the southern side of the same hill as the previous one, which is home to two 1940s housing projects that are being redeveloped into a mixed-income neighborhood by a private company contracted to redesign the neighborhood. ${ }^{24}$ The redesigning process included consultations with the community to ask what type of facilities they would like included, one of which was a garden to grow vegetables. Thus, in 2010, raised beds were made out of wood and set up outside the housing project's family resource center. Importantly, this was created as a temporary garden, since after the redevelopment was completed a new one was 
created one block down the hill in early 2013, so this was a first step in a work in progress. Part of the redevelopment project involved fixing the neighborhood's geographic isolation by restoring the perpendicular gridiron pattern of the streets in the area so as to reconnect it with the rest of the city's fabric, and particularly with the north side of the hill. Of course this is a double-edged sword, because it is undeniably an objective improvement for housing-project residents to be connected to the rest of the city, as many of the social issues they are faced with are correlated with isolation, such as lack of access to employment or to healthy food. But reconnecting this area will also make it more attractive, draw in higher-income residents and ultimately shoot up real estate value and rents. In this social engineering project, neighborhood revitalization is typically imbued with a reformist uplift ambition which involves "inculcating a strong work ethic and steady work habits," as Pudup says of turn of the twentieth-century school gardens, which is an explicit part of the interviewed Junior Community Builder's discourse. ${ }^{25}$

But additionally, the social uplift endeavor consists in inculcating healthy dietary habits and an ethos of self-help. The city's contractor in the redevelopment initiative presents itself as "not a service provider," and insists that its "three full-time staff are working with community leaders and organizations to increase their capacity to serve residents and increase resident involvement in existing programs." Thus various community-building "programs and projects" are underway, including a "Monthly Healthy Living Workshop" where a registered dietician "teach[es] a Healthy Living Workshop which combines healthy cooking demonstrations, education, and exercise." ${ }^{26}$ Such a program is not identical with the garden project, yet it is directly connected with it, both in terms of location-the premises are contiguous-and of visionencouraging involvement and agency through education. The organization thus seems to follow a rather vertical dynamic where knowledge and skills are handed down from organizers to recipients.

Ats the same time, however, participation in the activities triggered by the garden is real. On "garden workdays," twice a week, residents do spend time at the garden and engage in lively, congenial socializing. Anecdotal evidence is provided by the fact that the interviews I recorded on location are sometimes hard to transcribe due to the loud talking and laughing in the background. ${ }^{27}$ Residents have indeed taken to the moveable mural-painting workshop, the Zumba and meditation classes, the walking club and gardening sessions that are offered by the agency created by the contractor to connect with the residents. ${ }^{28}$ This tends to confirm one of McClintock's insights, which runs counter to the standard narrative that seemingly radical endeavors accidentally serve neoliberal interests. According to McClintock, seemingly neoliberal or neoliberal-friendly policies may inadvertently facilitate or even foster more radical or subversive appropriations. ${ }^{29}$ In the organized garden project under study, the claim of community ownership of the neighborhood in fact resulted from the redeveloping 
agency's seemingly less-than-candid commitment to "broadly engage the community in both master planning and community building efforts." 30

What is striking, though, when contrasting the dynamics around this organized garden project with the first one in this study, is the fact that it is built on a service-providing model, with paid staff and a preset calendar of activities. This pattern, however, is very much in keeping with San Francisco's reputed model of municipal liberalism that relies on a decentralized network of localized, community-based serviceproviding organizations and where social welfare goes hand in hand with a democratic rhetoric of civic engagement and participation. ${ }^{31}$ But there is a fine line between grassroots community-building and the more top-down, missionary reformist endeavors this project represents. We may venture that the difference is not just a question of top-down versus bottom-up initiative. Heeding the insight of David Adams and Michael Hardman, attention must also be paid to the participants' motivations and interpretations of the use of space..$^{32}$ In this sense, the first garden in this study indeed presents a much less ambiguous model altogether than the third one, for despite its six-digit budget, it has in fact a rather light-weight organization, which is essentially an enabling structure. That is to say it does not have a preset agenda, but an openended one, and the emphasis is less on the content than on the process -not on the what, but on the how.

\section{Conclusions}

The point of this study has not been to offer a definitive answer to the question of whether organized garden projects counteract or encourage gentrification, for the answer to such a question has to be a mixed one. And the study's purpose has not been to pass favorable judgment on some projects and unfavorable judgment on others, although that is partly unavoidable. Rather, my goal has been to better understand how apparently very similar gardens, in fact, involve very different, possibly antithetical dynamics. The variations among the three examples I have examined show that whereas the second garden under study rather unambiguously enhances gentrification, the third one stands halfway between facilitating and merely accompanying it, while the first one resists it, but mainly in a symbolical, immaterial-although by no means insignificant-way.

These differences have to do less with what kind of greening or gardening goes on in the various projects than with the type of decisionmaking process and with the way the residents' community is engaged. This is also where we can situate the difference between a serviceprovider-to-client relation, on the one hand, and communityempowerment, on the other. Ultimately, in order to understand what urban gardening can really do about gentrification, it is crucial to focus on motives and meanings. Thus, beautification does not, in and of itself, 
either enhance gentrification or fend it off. It is the meaning that participants inscribe in their practice that endows, or fails to endow, organized garden projects with collective empowerment potential. This, in turn, means that low-income communities besieged with gentrification may, and do, use gardening as a weapon against their disappearance. Such practices can be deemed hopeless, considering the disproportionate extent of the problem they seek to address, and indeed they cannot actually reverse the trend of gentrification. But, like the "weapons of the weak" identified by James C. Scott, they unobtrusively challenge gentrification's legitimacy and hence, symbolically, its irresistibility. ${ }^{33}$

\section{NOTES}

\section{1.}

Rich E. DeLeon, Left-Coast City. Progressive Politics in San Francisco, 19751991 (Lawrence: University of Kansas Press, 1992); Stephen J. McGovern, The Politics of Downtown Development. Dynamic Political Cultures in San Francisco and Washington, D.C. (Louisville: University of Kentucky Press, 1998); Chester Hartman, City for Sale. The Transformation of San Francisco (Berkeley: University of California Press, 2002).

2. Karen Schmelzkopf, "Urban Community Gardens as Contested Space," Geographical Review 85/3 (1995): 364-381; "Incommensurability, Land Use, and the Right to Space: Community Gardens in New York City," Urban Geography 23/4 (2002): 323-343; Christopher M. Smith and Hilda E. Kurtz, "Community Gardens and Politics of Scale in New York City," Geographical Review 93/2 (2003): 193-212; Miranda Martinez, "Attack of the Butterfly Spirits: The Impact of Movement Framing by Community Garden Preservation Activists," Social Movement Studies 8/4 (2009): 323-339; Sandrine Baudry, "Reclaiming Urban Space as Resistance: The Infrapolitics of Gardening," Revue française d'études américaines 131 (2012): 32-48.

3. John Gallagher, Revolution Detroit: Strategies for Reinvention (Detroit: Wayne State University Press, 2013); Yuki Kato, Catarina Passidomo, and Daina Harvey, "Political Gardening in a Post-disaster City: Lessons from New Orleans," Urban Studies 51/9 (2014): 1833-1849.

4. Richard Florida, The Rise of the Creative Class and How It's Transforming Work, Leisure, Community and Everyday Life (New York: Basic Books, 2002).

5. William Issel, "Liberalism and Urban Policy in San Francisco from the 1930s to the 1960s," The Western Historical Quarterly 22/4 (1991): 431-450; Philip J. Ethington, The Public City. The Political Construction of Urban Life in San Francisco, 1850-1900 (New York: Cambridge University Press, 1994); DeLeon, Left-Coast City.

6. Mary Beth Pudup, "It Takes a Garden: Cultivating Citizen-Subjects in Organized Garden Projects," Geoforum 39/3 (2008): 1228-1240. 
7. Author's interview with the garden project's managing director (21/07/2012).

8. Sandrine Baudry, "Les community gardens de New York City: de la désobéissance civile au développement durable," Revue française d'études américaines 129 (2011): 73-86.

9. Noah Quastel, "Political Ecologies of Gentrification," Urban Geography 30/7 (2009): 694-725; Melissa Checker, “Wiped Out by the 'Greenwave': Environmental Gentrification and the Paradoxical Politics of Urban Sustainability," City \& Society 23/2 (2011): 210-229; Carolin Mees and Edie Stone, "Zoned Out: The Potential of Urban Agriculture Planning to Turn Against its Roots," Cities and the Environment 5/1 (2012): Article 7; Eliot M. Tretter, "Contesting Sustainability: 'SMART Growth' and the Redevelopment of Austin's Eastside," International Journal of Urban and Regional Research 37/1 (2013): 297-310.

10. Author's interview with the garden project's managing director (21/07/2012).

11. Rolf J. Pendall, Arthur C. Nelson, Casey J. Dawkins, and Gerrit J. Knaap, "Connecting Smart Growth, Housing Affordability, and Racial Equity," in The Geography of Opportunity: Race and Housing Choice in Metropolitan America, ed. Xavier N. De Souza Briggs (Washington: Brookings Institution, 2005): 219246; Andrew Aurand, "Density, Housing Types and Mixed Land Use: Smart Tools for Affordable Housing?," Urban Studies 47/5 (2010): 1015-1036.

12. Garden project website, online (accessed 05/04/2014).

13. Author's interview with the garden project's initiator and managing director $(31 / 07 / 2012)$

14. Jackelyn Hwanga and Robert J. Sampson, "Divergent Pathways of Gentrification: Racial Inequality and the Social Order of Renewal in Chicago Neighborhoods," American Sociological Review 79/4 (2014): 732-734; Richard Van Deusen, "Public Space Design as Class Warfare: Urban Design, the 'Right to the City' and the Production of Clinton Square, Syracuse, NY," GeoJournal 58/2-3 (2002): 149-158; Sonia Arbaci and Teresa Tapada-Berteli, "Social Inequality and Urban Regeneration in Barcelona City Centre: Reconsidering Success," European Urban and Regional Studies 19/3 (2012): 287-311.

15. United States Census, Census Explorer, http://curvaceousness/ censusexplorer (accessed 28/04/2015); San Francisco Planning Department, San Francisco Neighborhoods Socio-Economic Profiles, American Community Survey 2005-2009 (May 2011). This is one of the neighborhoods in the San Francisco metropolitan area with the highest creative class share of its population (Richard Florida and Sara Johnson, Class-Divided Cities: San Francisco Edition, The Atlantic Citylab, 1 April 2013, http://www.citylab.com [accessed 28/04/2015]).

16. Garden project website, online (accessed 05/04/2014); author's interview (31/07/2012).

17. Garden project website, online (accessed 05/04/2014).

18. Author's interview (31/07/2012).

19. Garden project website, online (accessed 05/04/2014).

20. Author's interview (31/07/2012).

21. Quastel, "Political Ecologies of Gentrification": 705.

22. Nathan McClintock, "Radical, Reformist, and Garden-variety Neoliberal: Coming to Terms with Urban Agriculture's Contradictions," Local Environment: The International Journal of Justice and Sustainability 19/2 (2014): 147-171. 
23. Efrat Eizenberg, "The Production of Contesting Space: Community Gardens and the Cultivation of Social Change," paper presented at the "Open Space: People Space' conference, the OPENspace Research Centre, Edinburgh, UK, October 27-29, online (accessed 30/03/2014); "The Changing Meaning of Community Space: Two Models of NGO Management of Community Gardens in New York City," International Journal of Urban and Regional Research 36/1 (2012): 106-120.

24. Author's interview with a Junior Community Builder for the garden project (27/06/2012).

25. Pudup, "It Takes a Garden”: 1230; author's interview (27/06/2012).

26. Neighborhood redevelopment project's website, online (accessed 22/02/2015).

27. Author's interview with two garden project volunteers and one garden project manager (27/06/2012).

28. Neighborhood redevelopment project's website, online (accessed 22/02/2015).

29. McClintock, "Radical, Reformist, and Garden-variety Neoliberal”: 159.

30. Neighborhood redevelopment project's website, online (accessed 22/02/2015).

31. DeLeon, Left-Coast City, 13-25; McGovern, The Politics of Downtown Development, 33-39, 87-143.

32. David Adams and Michael Hardman, "Observing Guerrillas in the Wild: Reinterpreting Practices of Urban Guerrilla Gardening," Urban Studies 51/6 (2014): 1103-1119.

33. James C. Scott, Weapons of the Weak: Everyday Forms of Peasant Resistance, New Haven: Yale University Press, 1985.

\section{ABSTRACTS}

San Francisco is known for its small acreage and high population density. Due to its attractiveness, the city has been subjected to a housing shortage, skyrocketing real-estate rates, and a steady process of gentrification over the past 20 years in particular. Access to public spaces and deliberation, negotiation, and conflicts over the proper uses and appearance of such spaces is one aspect of the visible, contested transformation of San Francisco. Whether and how urban territories are appropriated or embellished can be rather contentious, for beautification may enhance the attractiveness of otherwise disreputable neighborhoods. Traditionally workingclass, ethnic- and racial-minority areas are thus regarded nowadays as a new frontier of middleto upper-middle-class, mainly white residential expansion. Organized and informal garden projects are interventions in public spaces that improve the quality of residents' lives and hence raise the question whether they heighten the gentrifying transformation of such neighborhoods, or whether they may support inhabitants' resistance to being pushed out. This question is especially crucial since the municipal government is a strong proponent of urban greening and the City of San Francisco has a rather ambivalent attitude when it comes to balancing poor people's socioeconomic rights with the tax revenue generated by urban development and the 
resulting influx of households in the upper income bracket. This contribution examines three significantly different garden projects in San Francisco. What in a garden project makes it lean toward the empowerment of a neighborhood's current residents, or toward their displacement? Or does this question simply make sense at all? Can urban gardening have any impact whatsoever on such large-scale socioeconomic phenomena as the city's changing demographics? Are garden projects even intended to address gentrification and the changing face of the city? And if so, are they somehow effective, simply pointless, or can they actually be detrimental and counterproductive?

\section{INDEX}

Keywords: community-building, empowerment, gentrification, resistance, San Francisco, urban garden projects

\section{AUTHOR}

\section{GUILLAUME MARCHE}

University Paris-Est Creteil 